\title{
Latent and Eggs Production of Banggai Cardinal (Pterapogon kauderni, Koumans 1933) on Various Salinity Levels: Conservation Efforts
}

\author{
Atiek Pietoyo ${ }^{1}$, Sri Andayani ${ }^{2}$, Agoes Soeprijanto ${ }^{2}$ \\ ${ }^{1}$ Master Program of Aquaculture, Faculty of Fisheries and Marine Sciences, University of Brawijaya, Malang, Indonesia \\ ${ }^{2}$ Department of Aquaculture, Faculty of Fisheries and Marine Sciences, University of Brawijaya, Malang, Indonesia
}

\begin{abstract}
The aim of this study is to determine the best salinity level on latent and eggs production of Banggai Cardinal (Pterapogon kauderni Koumans 1993) based on first brood and brood production of Banggai Cardinal in the treatment. Water quality measurement was carried out every day to maintain water quality. Water quality measurement showed suitable salinity for Banggai Cardinal breeding. Brood latent showed no significant difference between the treatments. Total of $27 \mathrm{ppt}$ is the level of salinity for Banggai Cardinal reproduction to gain positive respond on eggs production (42.3333 \pm 7 eggs).
\end{abstract}

Keywords: Banggai Cardinal, Eggs Production, Latent, Salinity.

\section{INTRODUCTION}

Indonesia has great amount of sea biodiversity which become susceptible due to human activity these days. Trading finfish as fish tank can lead a marine species to be endangered species $[1,2]$. Cardinal fish is a marine species which spread around temperate and tropical region [3]. Banggai Cardinal is an endemic Indonesian marine finfish species that threatened by human activity (e.g. over fishing). International trading of Banggai Cardinal was 50.000-118.000 each months and the trend tend to increase. Most Banggai Cardinal trades are comes from nature [4]. As result, Cardinal Banggai was on the red list of International Union for Conservation of Nature [5]. Therefore, understanding the breeding method is needed to conserve Banggai Cardinal population in the nature [6].

Banggai Cardinal is a marine fish species [3]. Similar to other marine fish, it is affected by external and internal factor such as physiological aspect of fish brood. Internal factors that affect brood physiology are gonad repoduction, maturity, etc [7]. Whereas, salinity as the main external factor which play important role on fish brood physiology. Salinity affects osmoregulation and metabolism of marine fish [8]. Thus, this study is aimed to determine the best salinity level refer to the production of brood's latent and fecundity of Banggai Cardinal.

\footnotetext{
* Correspondence author:

Atiek Pietoyo

Email : atiek.bbl@gmail.com

Address : Master Program of Aquaculture, University of Brawijaya, Jl. Veteran Malang, 65145
}

\section{MATERIALS AND METHODS}

\section{Brood preparation}

On August 2015, Banggai Cardinal brood stock (body length $3 \pm 0.2 \mathrm{~cm}$ ) were collected from Banggai archipelago (South Sulawesi province, Indonesia) and transported to the laboratory in Centre of Marine Aquaclture (Balai Besar Perikanan Budidaya Laut) Lampung within 8 hours. Banggai Cardinal brood stock adapted in 9 aquarium $\left(100 \times 50 \times 50 \mathrm{~cm}^{3}\right)$ filled with marine water (80\%). Total 3 pairs of Banggai Cardinal were adapted in each aquarium for 2 days and feed with artemia 3 times a day (ad satiation).

\section{Treatment}

The selected Banggai Cardinal brood stock in solitary aquarium partition $\left(20 \times 30 \times 50 \mathrm{~cm}^{3}\right)$ filled with marine water $(80 \%)$ was treated with 3 different levels of salinity $(27,30$ and $33 \mathrm{ppt})$ for 3 replications. Marine water diluted with fresh water or added with $\mathrm{NaCl}$ (Sigma Aldritch) to gain treated marine water concentration. Salinometer (TDS 10, Dongrun-China) was used as salinity measurement tools. Marine water in solitary aquarium was replaced $75 \%$ for every 5 days to maintain water quality.

\section{Water Quality}

Temperature and DO measured with Fischer Scientific, Traceable Portable Dissolve Oxygen Meter Pen. The acidity $(\mathrm{pH})$ was measured with Fischer Scientific "accumet" AP110 Portable pH meter. Furthermore, total Ammonia [9] and nitrite [10] were also measured. Water quality measurement conducted every day during laboratory works. 


\section{Latent}

Latent is the time needed for a fish to breed on treatment conditions. Brood latent is the time it's takes to spawn (days) measured based on Hopkins and Tamaru method [11].

\section{Eggs production}

Banggai Cardinal is a mouth breeding marine finfish species [12]. Eggs production are the number of eggs that taken after spawning. Eggs were removed from mouth and counted. Eggs production was measured on mouth breed habit of Banggai Cardinal [13].

\section{Statistical analysis}

SPSS 17 for Windows was used for statistical data analysis. Normality analysis was followed by One-way ANNOVA for normal data. Further, we used Tukey post hoc analysis. Statistical analysis was set at $p \leq 0.05$ for differences of treatment.

\section{RESULT AND DISCUSSION}

Water quality measurement (Table 1) during laboratory works was considered suitable for the requirement of Banggai Cardinal reproduction conditions. Suitable conditions for organism to live are based on temperature, $\mathrm{DO}, \mathrm{pH}$, nitrite and total ammonia [14].

Table 1. Water quality during Banggai Cardinal breed affected different salinity levels

\begin{tabular}{lccccccccc}
\hline \multirow{2}{*}{ Parameter } & \multicolumn{9}{c}{ Salinity } \\
\cline { 2 - 11 } & 27 & 30 & 28,6 & 27 & 30 & 30 ppt & & 33 ppt \\
\cline { 2 - 10 } & Min & Max & Avg & Min & Max & Avg & Min & Max & Avg \\
\hline Temperature (C) & 4.06 & 5.45 & 4.79 & 4.47 & 5.60 & 4.99 & 4.37 & 5.35 & 4.85 \\
DO (mg/L) & 7.96 & 8.23 & 8.09 & 7.87 & 8.37 & 8.05 & 7.88 & 8.32 & 8.04 \\
pH & 0.046 & 0.221 & 0.133 & 0.043 & 0.191 & 0.141 & 0.045 & 0.248 & 0.138 \\
Nitrite (mg/L) & 0.039 & 0.193 & 0.119 & 0.041 & 0.176 & 0.119 & 0.034 & 0.195 & 0.115 \\
Total Ammonia (mg/L) & & & & & &
\end{tabular}

\section{Latent}

Fish ability to adapt depends on the existing conditions [15]. Finfish adaptation to the new environment condition could be measured by its spawning [16]. Brood latent showed finfish adapted while brood latent value does not changed much. Brood latent showed no significant difference ( $p>0.05$ ) among treatment during laboratory works (Table 2). It was also means that laboratory condition was suitable for Banggai Cardinal breeding compared to their habitat on the nature. Cardinal Banggai lives on habitat with salinity range 29-35 ppt [17].

\section{Eggs Production}

Brood fecundity is the correlation of energy needs for the fish growth and reproduction [18]. Optimum range of energy within could be used to produce eggs in maximal number [19]. Increasing of brood fecundity value on mature finfish expressed their reproduction activity [20]. Laboratory works showed increasing brood fecundity value was affected on various salinity levels (Table 2). Moreover, statistical analysis showed significant difference $(p \leq 0.05)$ among treatment. Highest brood fecundity value was on the treatment 27 ppt of salinity. Higher brood fecundity value represented higher reproduction activity [18].
Table 2. Brood parameter of Banggai Cardinal breed affected by different salinity levels

\begin{tabular}{lccc}
\hline \multirow{2}{*}{ Parameter } & \multicolumn{3}{c}{ Salinity (ppt) } \\
\cline { 2 - 4 } & $\mathbf{2 7}$ & $\mathbf{3 0}$ & $\mathbf{3 3}$ \\
\hline Latent (days) & $43.1111^{\text {nd }} \pm 7$ & $42.1111^{\text {nd }} \pm 7$ & $42.6667^{\text {nd }} \pm 7$ \\
Brood fecundity & $42.3333^{\mathrm{b}} \pm 7$ & $36.1111^{\mathrm{ab}} \pm 1$ & $30.6667^{\mathrm{a}} \pm 3$ \\
(eggs) & & & \\
\hline *superscript indicated significant differences & among \\
treatment, nd = not significant differences
\end{tabular}

\section{CONCLUSION}

Salinity level at $27 \mathrm{ppt}$ was the best condition for reproduction of Banggai Cardinal. It was giving best respond on brood fecundity during laboratory works on this study.

\section{REFERENCES}

[1] ITPC (International Trade Promotion Center). 2011. Market Brief: HS 0301.10 ikan hias. Osaka.

[2] Foster, S.J., A.C.J. Vincent. 2004. Life history and ecology of seahorses: implications for conservation and management. J. Fish Biol. 65. 1-61.

[3] Galarza, J.A., S. Roques, J. Carreras-Carbonell, E. Macpherson, G.F. Turner, C. Rico. 2007. Polymorphic microsatellite loci for the cardinal fish (Apogonimberbis). Conserv. Genet. 8. 1251-1253.

[4] Vagelli, A.A., M.V. Erdmann. 2002. First comprehensive ecological survey of the 
Banggai Cardinalfish, Pterapogon kauderni. Environ. Biol. Fishes. 63(1). 1-8.

[5] Allen, G.R. 2000. Threatened fishes of the world: Pterapogon kauderni Koumans, 1933 (Apogonidae). Environ. Biol. Fishes. 57(2). 142-142.

[6] Agarwal, N.K. 2008. Fish reproduction. APH Publishing Coorporation: New Delhi.

[7] Affandi, R., U.M. Tang. 2002. Fisiologi hewan air. Riau University Press: Pekanbaru, Riau.

[8] Wardoyo. 1991. Effects of different salinity levels and acclimation regimes on survival, growth, and reproduction of three strains of Tilapia nilotica and Red Tilapia nilotica Hybrid. Dissertation Abstracts. International Part B: Science and Engineering, 51-77.

[9] Emerson, K., R.C. Russo, R.E. Lund, R.V. Thurston. 1975. Aqueous ammonia equilibrium calculations: effect of $\mathrm{pH}$ and temperature. J. Fish. Res. Board Can. 32. 2379-2383.

[10] Leonore, S.F. 1998, Standard methods for the examination of water and waste water No. 3112, 20 ${ }^{\text {th }}$ Ed. APHA, AWWA, WEF: Washington DC.

[11] Hopkins, S., C.S. Tamaru,.2005. Manual for the production of the Banggai Cardinalfish, Pterapogon kauderni, in Hawaii. University of Hawaii School of Ocean and Earth Science and Technology: Hawaii.

[12] Vagelli, A.A. 2011. The Banggai Cardinal fish: natural history, conservation, and culture of Pterapogon kauderni. John Wiley and Sons: UK.

[13] Vishwas Rao, M., T.T. Ajith-Kumar 2014. Captive breeding and hatchery production of mouth brooding jewel Cardinal Perch, Pterapogon Kauderni, (Koumanns, 1933) using brackish water: the role of live prey and green water enrichment in juvenile production. J. Aquacult. Res. Dev. 5(7). 1-7.

[14] Wolters, W., A. Masters, B. Vinci, S. Summerfelt. 2009. Design, loading, and water quality in recirculating systems for Atlantic salmon (Salmo salar) at the USDA ARS National Cold Water Marine Aquaculture Center (Franklin, Maine). Aquacultu. Eng. 41(2). 60-70.

[15] McLean, E., R.H. Devlin, J.C. Byatt, W.C. Clarke, E.M. Donaldson. 1997. Impact of a controlled release formulation of recombinant bovine growth hormone upon growth and seawater adaptation in Coho and Chinook Salmon. Aquaculture. 156. 113-128.

[16] Nur, B., B.P.B.I. Hias. 2011. Studi domestikasi dan pemijahan Ikan Pelangi Kurumoi (Melanotaenia parva) sebagai tahap awal upaya konservasi Ex-Situ. In: Proceeding of the $3^{\text {rd }}$ National Forum on Fisheries Resources Empowerment.

[17] Ndobe, S., E.Y. Herawati, D. Setyohadi, A. Moore, M.L. Palomares, D. Pauly. 2013. Life history of Banggai Cardinalfish, Pterapogon kauderni (Actinopterygii: Perciformes :Apogonidae), from Banggai Islands and Palu Bay Sulawesi Indonesia. Acta ichthyologicaet piscatorial. 43(3). 237-250.

[18] Rustidja. 2001. Feromon ikan. University of Brawijaya: Malang

[19] Committee on Animal Nutrition. 1993. Nutrient requirements of fish. Course Technology. National Research Council (US).

[20] Morgan, M.J. 2008. Integrating reproductive biology into scientific advice for fisheries management. J. Northwest Atlantic Fish. Sci. 41. 37-51. 